\title{
A ARQUEOLOGIA DA INTEGRAÇÃO CURRICULAR: ENREDO HISTÓRICO DA EDUCAÇÃO PROFISSIONAL E SUA INTERFACE COM O CURRÍCULO INTEGRADO
}

\author{
BENFATTI, Xênia Diógenes* \\ VITORINO, Grace Troccoli** \\ LEITINHO, Meirecele Calíope ${ }^{* * *}$
}

\begin{abstract}
RESUMO
Nas últimas décadas, as dificuldades e as incompreensões conceituais acentuaram a frágil identidade do Ensino Profissionalizante na Educação Básica. Desse modo, remontar sua história e relacioná-la ao currículo integrado constitui-se o propósito deste artigo, que foi desenvolvido como parte da pesquisa de doutorado intitulada $O$ Currículo do Ensino Médio Integrado: da intenção à realização, concluída em novembro de 2011. A pesquisa realizada para este estudo caracterizou-se como qualitativa e assumiu metodologicamente o aspecto de bibliográfica, cujas categorias teóricas definidas foram: a história da Educação Profissional; o Ensino Médio e sua articulação com a formação para o Trabalho e o currículo integrado na Educação Profissional. O problema de pesquisa foi tomado pela questão: Como a concepção de currículo integrado surge na Educação Profissional brasileira? Os resultados indicam que os contornos e as nuanças contidos na história da Educação Profissional são suportes arqueológicos significativos para compreensão e análise da identidade conceitual e estrutural observada hoje nas escolas que integram o Ensino Médio à Educação Profissional. A título de conclusão, pode-se inferir que as resistências, as mudanças e os embates são aspectos intrinsecamente relacionados ao passado histórico da Educação Profissional brasileira; não há, portanto, como analisar o presente sem relacionálo à sua história.
\end{abstract}

PALAVRAS-CHAVE: Ensino Médio. Educação Profissional. História. Currículo integrado.

\footnotetext{
* Doutora em Educação pela Universidade Federal do Ceará. Professora e pesquisadora da Universidade de Fortaleza nas áreas de Avaliação, Currículo e Formação de professores. E-mail: xenia@unifor.br

** Doutora em Educação pela UFC, professora e pesquisadora da Universidade de Fortaleza. E-mail: gracet@unifor.br

*** Pós Doutora pela Universidade de Brasília, professora e pesquisadora da UECe e UFC. E-mail: meirecele@terra.com.br

$=======$

Revista e-Curriculum, São Paulo, v.16, n.3, p. 751-767 jul./set.2018

e-ISSN: $1809-3876$

Programa de Pós-graduação Educação: Currículo - PUC/SP

http://revistas.pucsp.br/index.php/curriculum
} 


\author{
BENFATTI, Xênia Diógenes* \\ VITORINO, Grace Troccoli** \\ LEITINHO, Meirecele Calíope ${ }^{* * *}$
}

\begin{abstract}
In the last decades, the difficulties and conceptual misunderstandings emphasized the fragile identity of Professional Tuition in Basic Education. Thus, the purpose of this paper is reassemble its history and relate it to integrated curriculum, which was developed as part of a PhD research entitled "The Curriculum of the Integrated High School: from intention to accomplishment", concluded in November 2011. The research conducted for this study was characterized as qualitative and methodologically assumed the aspect of bibliographic, whose defined theoretical categories were: the history of Professional Education; the High School and its connection with education for Work and the integrated curriculum in Professional Education. The research problem was taken up by the question: How does the conception of integrated curriculum emerge in the Brazilian Professional Education? The results indicate that the profile and nuances contained in the history of Professional Education are a significant archaeological support for understanding and analysis of conceptual and structural identity observed in schools today that integrate High School to Professional Education. In conclusion it can be inferred that the resistance, change and conflicts are intrinsically related aspects to the historical past of the Brazilian Professional Education; therefore there is no possibility to analyze the present without relating it to its history.
\end{abstract}

KEYWORDS: High school. Professional Education. History. Integrated curriculum.

\footnotetext{
${ }^{*} \mathrm{PhD}$ in Education from the Universidade Federal do Ceará (UFC). Professor and researcher at the Universidade de Fortaleza in the areas of Evaluation, Curriculum and Teacher Education. E-mail: xenia@unifor.br

** $\mathrm{PhD}$ in Education from the UFC, professor and researcher at Universidade de Fortaleza. Email:gracet@unifor.br

*** Postdoctoral from the Universidade de Brasília, professor and researcher at Universidade Estadual do Ceará and UFC. E-mail: meirecele@terra.com.br
} 


\section{INTRODUÇÃO}

Mudanças relevantes caracterizaram a organização e os paradigmas conceituais proclamados ou velados historicamente pela Educação Profissional brasileira. Remontar a história da Educação Profissional e relacioná-la ao currículo integrado foi o desafio que guiou a elaboração deste artigo, que se propõe apresentar os elementos e os pressupostos que desencadearam a ideia de integração curricular do Ensino Médio ao Ensino TécnicoProfissional.

Os percalços na trajetória da política da Educação Profissional no Brasil revelam que, nas últimas décadas, as dificuldades e as incompreensões conceituais marcam a frágil identidade do Ensino Profissionalizante na Educação Básica. As dificuldades e as incompreensões também podem ser observadas no Ensino Médio, cuja identidade está ainda fortemente marcada pelo ensino propedêutico, de caráter conteudista e até então direcionado ao vestibular ${ }^{1}$.

A integração do Ensino Médio e da Educação Profissional pode ser observada na Lei de Diretrizes Bases da Educação Nacional No 9.394/1996 (BRASIL, 1996), quando explicita, logo em sua introdução, que a educação escolar deverá vincular-se ao mundo do trabalho e à prática social (Art. $1^{\circ}, \S 2^{\circ}$ ), e complementa, no Art. $2^{\circ}$ que sua finalidade é a de desenvolver e preparar o educando para o exercício da cidadania e sua qualificação para o trabalho (BRASIL, 1996). Essa finalidade ganha certa especificidade no Ensino Médio, uma vez, que dentre outras finalidades, traz o trabalho como princípio de formação necessário a todos os egressos, e não somente aos egressos da Educação Profissional. Para Frigotto, Ciavatta e Ramos (2005), a efetivação preconizada pela atual LDB supera o modelo em vigor desde 1971, que admitia dois percursos distintos para o Ensino Secundário: um destinado aos jovens interessados no Ensino Superior, de caráter propedêutico; e outro, de caráter técnico-profissional, destinado aos jovens de baixa renda que precisavam de formação técnica para o exercício profissional.

As discussões acerca do currículo integrado, mais especificamente a integração do Ensino Médio à Educação Profissional emergiram com bastante entusiasmo na virada do século XX para o século XXI, quando o Governo Federal decidiu implementar como política pública educacional a oferta integrada do Ensino Médio e da Educação Profissional. Foi assim que 
surgiu a reintegração da Educação Profissional ao Ensino Médio com o Decreto Federal No 5.154, de 23 de julho de 2004 (BRASIL, 2004).

A aplicação da modalidade integrada, ainda recente no contexto brasileiro, apresenta registros limitados de pesquisas que denotem valores e dificuldades encontradas em sua implementação. Desse modo, esta pesquisa elucida aspectos relevantes e ainda não abordados para a avaliação dos currículos de Ensino Médio Integrado (EMI).

O trabalho realizado de natureza qualitativa e de aspecto bibliográfico buscou, por meio de incursão histórica da Educação Profissional, discutir os marcos legais, as concepções e/ou incompreensões sobre o currículo integrado. Esta pesquisa fez parte do trabalho realizado para a conclusão da tese de Doutorado O Currículo do Ensino Médio Integrado: da intenção à realização, de Xênia Diógenes Benfatti, concluída em novembro de 2011 pelo Programa de Pós-Graduação da Faculdade de Educação da Universidade Federal do Ceará.

\section{METODOLOGIA}

A natureza metodológica adotada para esta investigação seguiu predominantemente os contornos da abordagem qualitativa, caracterizada por Bogdan e Biklen (1994) como uma investigação que trabalha com indicadores descritivos; prioriza o processo e analisa os dados por meio da indução.

O procedimento metodológico usado foi o estudo bibliográfico realizado por meio de três categorias teóricas: a história da Educação Profissional; o Ensino Médio e sua articulação com a formação para o Trabalho e o currículo integrado na Educação Profissional.

No que concerne à pesquisa bibliográfica, Gil (1991) indica que o estudo bibliográfico comece com a definição do problema de pesquisa. Para esta investigação, o problema de pesquisa delineado foi: Como a concepção de currículo integrado surge na Educação Profissional brasileira? Na sequência metodológica, a segunda fase da investigação foi desenvolvida por meio da seleção das peças que comporiam a revisão literária do assunto. Após a escolha das peças, foram identificados e selecionados os itens que seriam mais relevantes para a produção do texto científico e, por fim, foram discutidas as conclusões do estudo. $\mathrm{O}$ resultado da investigação foi sistematizado e será apresentado no item a seguir. 


\section{RESULTADOS E DISCUSSÕES}

O trabalho arqueológico de levantar os vestígios e os elementos históricos que denotam a integração curricular da Educação Profissional à Educação Geral tornou-se necessário, pois compreender o atual contexto requereu analisá-lo, interpretá-lo e relacioná-lo aos conceitos e aos fenômenos que, ao longo da história, foram deflagrados, ratificados, contestados, desvencilhados, traduzidos e sedimentados. Nesses termos, exibiremos a seguir os pressupostos históricos do currículo integrado, os elementos históricos que denotam a trajetória da Educação Profissional e sua relação com o atual contexto.

\subsection{Pressupostos históricos da integração curricular}

A formação integrada emerge historicamente da necessidade de superação da razão histórica da divisão social do trabalho e do conhecimento como reserva de capital intelectual. Para Ciavatta (2005), o(s) conceito(s) de integração articula(m)-se aos contextos históricos proclamados desde o Renascimento por meio dos utopistas, que nutriam o sonho do conhecimento e da arte como fenômenos que completariam a razão da existência humana; segue pelo século XIX com os socialistas utópicos; e chega ao século XX, que, por meio do materialismo histórico, dará força ideológica e material à integração, capaz de transformar as contradições e as desigualdades desenvolvidas pelo sistema político-econômico e seus meios de produção.

Para Kuenzer (2007), o desenvolvimento histórico do Ensino Médio e Educação Profissional sempre esteve de alguma forma (des)articulado, pois a dualidade estrutural respondia à oferta escolar do conhecimento: o Ensino Médio para os incluídos socialmente e o ensino Profissional para aqueles que deveriam apenas desenvolver o trabalho subordinado. Para a autora, a análise do desenvolvimento histórico do Ensino Médio e Profissional é necessária, pois traduz características do desenvolvimento social e econômico do país, bem como os limites de sua superação.

A ligação da escola ao trabalho e à ciência emerge, na contemporaneidade, como necessidade também apontada pelas forças capitalistas, pois o avanço tecnológico impôs à formação profissional o desenvolvimento de saberes que ultrapassassem a instrumentalização $=======$

Revista e-Curriculum, São Paulo, v.16, n.3, p. 751-767 jul./set.2018 e-ISSN: $1809-3876$ 
do trabalhador e que os qualificassem também para o trabalho intelectual. Trabalho, ciência e tecnologia deveriam ser, assim, difundidos como alicerces para a organização do trabalho escolar e para o desenvolvimento capital das sociedades, que enfrentam a concorrência do livre comércio e da globalização, assim como anota Kuenzer (1997, p. 36):

Neste sentido, a escola que se tem hoje já não serve sequer aos interesses do capitalismo, que busca superar concretamente as dificuldades que a aplicação rigorosa da divisão técnica do trabalho impõe ao seu desenvolvimento. Hoje, para o capital, o "gorila amestrado" não tem função a desempenhar. O capital precisa, para se ampliar, de trabalhadores capazes de desempenhar sua parte no acordo social imposto pelas relações de trabalho, pelo cumprimento dos seus deveres, e ao mesmo tempo capazes de incorporar as mudanças tecnológicas, sem causar estrangulamento à produção. Para tanto, a mera educação profissional já não é mais suficiente. Por isso, o próprio capital reconhece que os trabalhadores em geral precisam ter acesso à cultura sob todas as suas formas, para o que é indispensável uma sólida educação básica.

Portanto, cumpre-nos, desde essa análise preliminar, afirmar que historicamente a dualidade curricular prevaleceu sobre o modelo integrado. Implementá-lo requer a clareza dos embates políticos, sociais e econômicos, que serão travados para seu desenvolvimento, pois os vícios históricos consolidados podem ratificar ainda mais a dualidade estrutural e material, com o agravante de proclamá-la integrada sem que de fato possa assim caracterizar-se. Uma pseudointegração, gerada e sustentada como modelo de superação e transformação, pode ser tão perversa quanto o modelo dualista observado ao longo da história brasileira.

3.2 Vestígios históricos do entrelaçamento entre Educação e formação para o trabalho

Feitas as considerações sobre os pressupostos históricos da integração curricular, julgamos adequado explicitar os vestígios arqueológicos de ligação da Educação Escolar à formação para o trabalho. Cinco autores subsidiaram essa tarefa arqueológica: Frigotto, Ciavatta e Ramos (2005), Cunha (2000), Kuenzer (1997) e Manfredi (2002).

A colonização portuguesa trouxe mudanças substanciais à organização da sociedade brasileira, então não mais somente formada pelas diversas tribos indígenas, mas agregada aos europeus (os portugueses em sua maioria) e africanos (negros que eram comercializados para o trabalho escravo). A economia, predominantemente agroindustrial, era impulsionada pelos engenhos, que, além de cultivarem a cana-de-açúcar, produziam o açúcar². A clara divisão social imposta pela estrutura de organização do engenho, proprietário e escravos ou 
trabalhadores assalariados, impunha limite ao desenvolvimento de saberes e conhecimentos inerentes à formação profissional.

A expansão comercial do açúcar e a intensificação da atividade extrativa de minérios ensejaram a criação de núcleos urbanos e, neles, o surgimento de ofícios, como: pedreiros, ferreiros, artesãos (CUNHA, 2000). Nesse período, registra-se, também, a criação das primeiras escolas brasileiras: os colégios religiosos, estruturados principalmente pelos jesuítas; funcionavam como escolas-oficinas, que preparavam artesãos e trabalhadores para a construção, manutenção e prestação de serviços. Vale ressaltar que os primeiros registros de escolarização na educação brasileira relacionam-se à educação profissional. Acredita-se que tal fenômeno esteja ligado às necessidades impostas e deflagradas pelo desenvolvimento dos centros urbanos, bem como à escassez de serviços e produtos existentes. Como ressalta Manfredi (2002, p. 69):

Nas oficinas existentes nos colégios espalhados pelos diferentes pontos do Brasil, os irmãos-oficiais exerciam e ensinavam ofícios ligados a atividades de carpintaria, de ferraria, de construção de edifícios, embarcações, de pintura, de produção de tijolos, telhas, louça, etc., de fabricação de medicamentos, de fiação e tecelagem.

Ainda no período da colonização, Cunha (2000) descreve a existência das corporações de ofícios, que funcionavam como escolas de preparação e de qualificação profissional. Organizadas por corporações profissionais, havia o mestre, que registrava as aprendizagens desenvolvidas na mesa da irmandade, e cada mestre não podia ter mais de dois aprendizes. $\mathrm{O}$ período mínimo para a certificação declarada pelo mestre ao aprendiz era de quatro anos, mas, mesmo após a certificação, os aprendizes eram examinados por uma banca.

A atividade econômica, a estrutura e a organização da sociedade, no período colonial, denotaram a predominância dos conteúdos relacionados ao trabalho e à profissionalização, pois, nos currículos escolares, corporações de ofício e atividades não formais desenvolvidas nos engenhos, os conteúdos eram compostos somente pelos saberes referentes à Educação Profissional e sua identidade predominantemente definida pelo e no trabalho. Até aqui, observavam-se vestígios do currículo propedêutico e da clássica formação educacional ${ }^{3}$.

Outro aspecto importante a ressaltar é a relação do sistema escravocrata com a política social, pois as precárias condições de vida e a marginalização ao acesso dos serviços e dos bens culturais, desenvolvidas em quase três séculos, influenciaram na representação social dos $========$

Revista e-Curriculum, São Paulo, v.16, n.3, p. 751-767 jul./set.2018 e-ISSN: $1809-3876$ 
segmentos populacionais (negros e índios), bem como na concepção de trabalho, corroborando a distância de valor do trabalho intelectual do trabalho braçal, como exprime Manfredi (2002).

Em 1808, a Corte Portuguesa chegou ao Brasil (Rio de Janeiro) e sua vinda provocou mudanças significativas na política e na economia brasileira: na economia, a relação de exploração definida anteriormente pelo sistema agroindustrial é parcialmente substituída pelo sistema industrial de produção e comercialização; e, na política, emergem o conceito de Estado Nacional e a constituição do aparelho educacional escolar (CUNHA, 2000).

A educação escolar como oferta pública e estatal foi determinada pela expulsão da Companhia de Jesus em 1759. Segundo Cunha (2000), até o século XVII, os jesuítas mantinham, no Brasil, 25 residências religiosas, 36 missões e 17 colégios e seminários ${ }^{4}$. O Estado é levado a assumir de fato a responsabilidade da oferta da educação escolar brasileira com a expulsão dos jesuítas.

As análises extraídas dos dados históricos de Manfredi (2002) e Cunha (2000) sobre as primeiras instituições públicas de ensino evidenciam a identidade do Ensino Médio ${ }^{5}$ definida pelo caráter propedêutico e preparatório à universidade. Deve-se destacar o fato de que a prioridade política definida nesse período não foi a expansão do Ensino Primário e Secundário ${ }^{6}$, mas, sim, do Ensino Superior. Os vestígios históricos desse período contribuem para a concepção até hoje predominantemente mantida no Ensino Médio: centrado nos conteúdos disciplinares de caráter propedêutico, desarticulados do trabalho, cultura e ciência e voltados com ênfase para a preparação ao vestibular.

As escolas de Educação Profissional no Império trabalhavam com a oferta integrada de formação, porém os currículos eram desenvolvidos nas matérias disciplinares organizadas e desenvolvidas isoladamente. A extinção da escravatura, os movimentos de imigração e a expansão da cultura marcaram os últimos anos do Império e as primeiras décadas do período republicano (MANFREDI, 2002).

A aceleração da industrialização e da urbanização ensejaram novas necessidades de formação:

Durante o período chamado de Primeira República, que vai da Proclamação da República até os anos 30, o sistema educacional escolar e a Educação profissional ganhara nova configuração. As poucas e acanhadas instituições dedicadas ao ensino compulsório de ofícios artesanais e manufatureiros cederam lugar a verdadeiras redes de escolas, por iniciativas de governos estaduais, do governo federal e de outros protagonistas: A Igreja Católica, 
trabalhadores organizados em associações de mútuo socorro ou de natureza sindical, os quais contribuíram com algumas iniciativas, e membros da elite cafeeira (MANFREDI, 2002, p. 79-80).

Para Kuenzer (2007), a formação profissional como responsabilidade do Estado iniciase, de fato, em 1909, com a criação de 19 escolas de artes e ofícios nas diferentes unidades da Federação. A autora destaca que a finalidade prescrita para essas escolas relacionava-se a "educar, pelo trabalho, os órfãos, pobres e desvalidos da sorte, retirando-os da rua" (KUENZER, 2007, p. 27).

Manfredi (2002, p. 89) analisa esse contexto histórico e as iniciativas produzidas como "antídoto às ideias exóticas das lideranças anarco-sindicalistas", pois o desenvolvimento industrial capitalista fez surgir movimentos grevistas nos grandes centros urbanos. Por outros valores, os industriais compreendiam a Educação Profissional como ferramenta que impulsionaria o desenvolvimento e situaria o país frente aos países europeus e aos Estados Unidos.

As escolas de aprendizes artífices tinham currículos e metodologias diferenciadas das demais instituições de ensino elementar, e os ofícios lá desenvolvidos eram os de marcenaria, alfaiataria, sapataria e outros relacionados ao trabalho artesanal, o que distanciava o espírito da industrialização com o currículo desenvolvido (CUNHA, 2000). Na sinopse histórica descrita por Manfredi (2002) para a Educação Profissional nas primeiras décadas da República, destacam-se os seguintes aspectos relevantes para a análise dos currículos escolares:

Com base no exposto, foi possível notar que a Primeira República se caracterizou como um período de grandes transformações e de grandes transformações e de grande ebulição social, no qual se gestaram novas práticas e concepções de Educação Profissional: ao lado da concepção assistencialista e compensatória, surgiram a católico-humanista, orientada pelo trabalho como antídoto à preguiça, à vadiagem, e às ideias revolucionárias, a concepção anarco-sindidicalista de educação integral e, finalmente, a visão de formação profissional para o mercado de trabalho para o exercício de funções e atribuições dos pontos de trabalho, segundo os padrões do regime fabril e do trabalho assalariado capitalista. As concepções emergentes, somadas àquelas do período anterior, configurar-se-iam como matrizes político-pedagógicas de referência ao longo de todo o século XX (MANFREDI, 2002, p. 94).

Ainda para Kuenzer (1997), a dualidade estrutural é predominante no século XX. A estrutura e a organização do sistema escolar estavam voltadas ao Ensino Primário, seguido do 
Secundário propedêutico e, por fim, do Ensino Superior, este, sim, voltado à formação de profissionais. As etapas de formação eram sucessivamente consolidadas pelos exames de admissão ${ }^{7}$. Contudo, o acesso ao Ensino Superior (até 1942) só era possível mediante a conclusão do curso ginasial.

Os currículos dos cursos ginasiais propostos pela reforma de João Luiz Alves (1925), como expressa Kuenzer (1997), eram essencialmente propedêuticos e cobriam os estudos de Língua e Literatura Portuguesa, Línguas estrangeiras modernas, Matemática, Geografia, História, Física, Química, História Natural e Cosmografia, Filosofia, Sociologia, Desenho e Instrução Moral e Cívica. As formações profissionais destinadas ao comércio, à agricultura e ao magistério (o normal) eram inexpressivas e não davam acesso aos cursos superiores.

A Reforma de Francisco Campos, em 1932, não propôs mudanças para o currículo; no entanto, no que concerne à estrutura do ensino, surgiram os cursos complementares. Conforme explica Kuenzer (1997, p. 12):

Esses cursos, sempre propedêuticos, constituíram-se em propostas pedagógicas diferenciadas articuladas ao curso superior desejado: préjurídico, pré-médico e pré-politécnico. Os cursos complementares eram realizados nas próprias escolas de nível superior e tinham dois anos de duração, destinando-se aos que concluíam a $5^{\circ}$ série do curso ginasial.

Em 1942, com a Reforma de Gustavo Capanema e a promulgação das Leis Orgânicas, são extintos os cursos complementares e surge, propriamente, o Ensino Médio, que, no período explicitado, era denominado genericamente de colegial e apresentava duas modalidades: o científico e o clássico. O colegial tinha duração de três anos e destinava-se a preparar os estudantes para o ingresso no Ensino Superior. Os cursos normais, agrotécnicos, comerciais técnicos e industriais técnicos estavam no mesmo nível de formação, mas não permitiam o acesso ao nível superior, isso só era permitido mediante a exames de adaptação ${ }^{8}$. Contudo, vale registrar que, pela primeira vez, surgia a oportunidade de o egresso de curso profissionalizante ter acesso ao nível superior (KUENZER, 1997).

Nesse mesmo período, as escolas de artes e ofícios são transformadas em escolas técnicas, bem como são criados os sistemas de formação particular profissional: o Serviço Nacional de Aprendizagem Industrial (SENAI), em 1942, e o Serviço Nacional de Aprendizagem Comercial (SENAC), em 1946. 
A equivalência dos estudos realizados em cursos profissionais ao Ensino Secundário só aconteceria com a promulgação da Lei de Diretrizes e Bases da Educação Nacional (Lei N ${ }^{\circ}$ 4.024, de 20 de dezembro de 1961). Os currículos escolares passaram a mesclar a formação humanista clássica e as diversas formações profissionais, assim como descreve Kuenzer (2007, p. 29):

\begin{abstract}
Essa realidade sofre uma significativa alteração em 1961, com a promulgação da Lei de Diretrizes e Bases da Educação Nacional (Lei n 4.024-1961, a partir de mudanças ocorridas no mundo do trabalho. A diferenciação e o desenvolvimento crescente dos setores secundário e terciário, conduzem ao reconhecimento da legitimidade de outros saberes, que não só os de cunho acadêmico, na etapa que se caracteriza como tradicional nova, do ponto de vista do princípio educativo. Pela primeira vez, a legislação educacional reconhece a integração completa do ensino profissional ao sistema regular de ensino, estabelecendo-se a plena equivalência entre os cursos profissionalizantes e os propedêuticos, a fins de prosseguimento de estudos. Da mesma forma, os cursos do SENAI e SENAC podem ser organizados, cumpridas as exigências legais, de modo a equivaler aos níveis fundamental e médio.
\end{abstract}

A integração do ensino profissional ao sistema regular consolida-se por meio da LDB $\mathrm{N}^{\circ}$ 4.024/1961; entretanto, a organização manteria a dualidade estrutural e, somente uma década depois, em 1971, com a Lei No 5.692 (BRASIL, 1971), a dualidade foi substituída pela trajetória única e integrada: - Ensino Médio e Educação Profissional - cuja profissionalização passa a ser universal e compulsória no Ensino Médio (antes chamado de secundário). O currículo humanista-científico é substituído pelo científico-tecnológico. Para Manfredi (2002) e Kuenzer (1997, 2007), a ideia de universalização da educação profissional estava fortemente influenciada pelo interesse nacional em participar da economia internacional, pois, notadamente, a economia brasileira apontava para o ingresso do Brasil no bloco do Primeiro Mundo - isso tudo representado no ideário social, sobretudo marcado pelas políticas do regime militar.

A trajetória integrada não vingou e, quatro anos depois, por meio do Parecer do Conselho Federal de Educação No 76 -1975, a formação geral voltou como modelo curricular para o Ensino Médio (BRASIL, 1975). O fracasso precoce da formação integrada esteve relacionado, para Kuenzer (2007), às dificuldades de implantação e de implementação material do sistema integrado, bem como pela notória constatação de que a "euforia do milagre" do desenvolvimento econômico não chegaria aos patamares esperados.

Revista e-Curriculum, São Paulo, v.16, n.3, p. 751-767 jul./set.2018 
A precariedade e a escassez na formação profissional arrastam-se até 1982, quando, por meio da Lei $\mathrm{N}^{\mathrm{0}}$ 7.044, de 18 de outubro de 1982 (BRASIL, 1982), legitima-se a dualidade estrutural na formação do Ensino Médio, ratificando o que já se observava na organização do sistema público de ensino: a distinção da formação geral (o científico) da formação profissional (o profissionalizante).

\subsection{Surgimento do Ensino Médio integrado à Educação Profissional}

Com o advento da nova Lei de Diretrizes e Bases da Educação Nacional No 9.394/1996, o caráter de reintegração emerge e, nas seções dedicadas ao Ensino Médio e à Educação Profissional, a indicação de articulação está expressa ora como finalidade de formação do Ensino Médio, ora como orientação curricular da Educação Profissional.

A expressão mais contundente de integração aconteceu quando o Decreto Federal $N^{\circ}$ 5.154/2004 foi promulgado e, no âmbito da proposição, houve a necessidade que deflagrou a mudança: a reintegração da Educação Profissional ao Ensino Médio:

Art. $4^{\circ}$ A educação profissional técnica de nível médio nos termos dispostos no $\S 2$ o do art. 36 , art. 40 e parágrafo único do art. 41 da Lei no 9.394 , de 1996, será desenvolvida de forma articulada com o ensino médio, observados: I - os objetivos contidos nas diretrizes curriculares nacionais definidas pelo Conselho Nacional de Educação;

II - as normas complementares dos respectivos sistemas de ensino; e III - as exigências de cada instituição de ensino, nos termos de seu projeto pedagógico (BRASIL, 2004, p. 18).

Para Frigotto, Ciavatta e Ramos $(2005)^{9}$, compreender o contexto que deflagrou a integração do Ensino Médio à Educação Profissional requer a análise do contexto históricopolítico que antecedeu a reforma, bem como os embates ideológicos e políticos travados anteriormente à promulgação do Decreto $N^{\circ} 5.154 / 2004$, e que, no atual contexto, justificam as dificuldades e os problemas decorrentes das resistências e das negligências observadas na efetivação da integração curricular nas escolas de EMI.

$\mathrm{Na}$ retrospectiva e na análise das três últimas leis de diretrizes e bases educacionais, o Ensino Técnico profissionalizante pode sinteticamente ser representado por meio do Quadro 1 ilustrativo a seguir, que mostra a prescrição normativa e a indicação conceitual da Educação Profissional no Ensino Médio. 
Quadro 1 - A Educação Profissional: prescrição normativa e indicação conceitual nas Leis de Diretrizes e Bases Nacionais no período de 1971 a 1996

\begin{tabular}{|c|c|c|}
\hline $\begin{array}{l}\text { Leis de Diretrizes } \\
\text { e Bases }\end{array}$ & Prescrições normativas & Indicações conceituais \\
\hline Lei $N^{\circ} 5.692 / 1971$ & $\begin{array}{l}\text { Art. } 1^{\circ}-\mathrm{O} \text { ensino de } 1^{\circ} \text { e } 2^{\circ} \text { graus tem por } \\
\text { objetivo geral proporcionar ao educando a } \\
\text { formação necessária ao desenvolvimento } \\
\text { de suas potencialidades como elemento de } \\
\text { auto realização, qualificação para o } \\
\text { trabalho e preparo para o exercício } \\
\text { consciente da cidadania [...] } \\
\text { Art. } 21 \text { - O ensino de } 2^{\circ} \text { grau destina-se à } \\
\text { formação integral do adolescente. }\end{array}$ & $\begin{array}{l}\text { Integração Curricular (superação } \\
\text { do dualismo curricular) }\end{array}$ \\
\hline Lei $N^{\circ} 7.044 / 1982$ & $\begin{array}{l}\text { Art. } 4 \S 2^{\circ} \text { - A preparação para o trabalho, } \\
\text { no ensino de } 2^{\circ} \text { grau, poderá ensejar } \\
\text { habilitação profissional, a critério do } \\
\text { estabelecimento de ensino. }\end{array}$ & $\begin{array}{l}\text { Notória distinção da formação geral } \\
\text { (científica) e formação profissional. } \\
\text { A educação profissional é optativa } \\
\text { no ensino regular. }\end{array}$ \\
\hline Lei No 9.394/1996 & $\begin{array}{l}\text { Art. } 39-\text { A educação profissional, } \\
\text { integrada às diferentes formas de educação, } \\
\text { ao trabalho, à ciência e à tecnologia, conduz } \\
\text { ao permanente desenvolvimento de } \\
\text { aptidões para a vida produtiva. } \\
\text { Art. } 40-\text { A educação profissional será } \\
\text { desenvolvida em articulação com o ensino } \\
\text { regular ou por diferentes estratégias de } \\
\text { educação continuada, em instituições } \\
\text { especializadas ou no ambiente de trabalho. }\end{array}$ & $\begin{array}{l}\text { Articulação do Ensino Médio à } \\
\text { Educação Profissional. }\end{array}$ \\
\hline
\end{tabular}

\section{Fonte: As autoras}

O quadro ilustrativo, elaborado por meio dos estudos bibliográficos, revela a identidade da Educação Profissional assumida nas três leis de diretrizes e bases da educação nacional, e, nelas, a integração será preconizada na Lei $\mathrm{N}^{\circ} 5.692 / 1971$ e na Lei $\mathrm{N}^{\circ}$ 9.394/1996. O apartheid da Educação Profissional ao Ensino Médio será observado na Lei No 7.044/1982; posteriormente no Decreto $N^{o} 2.208 / 1997$ será consolidada a disjunção e, com o agravante da incongruência, pois a LDB No 9.394/1996 (promulgada um ano antes da publicação do Decreto) determinava, no Art. 40, o desenvolvimento da Educação Profissional em articulação com o ensino regular (BRASIL, 1996). Entretanto, o Decreto $N^{\circ} 2.208 / 1997$ contradizia tal orientação, firmando-se, portanto, a insustentabilidade normativa do Decreto ${ }^{10}$.

Nos bastidores da revogação do Decreto No 2.208/1997 e publicação do No 5.154/2004, registram-se fóruns de discussões nacionais, tais como: o Fórum Nacional em Defesa da Escola Pública (1988); e os Seminários Nacionais: Ensino Médio: construção política e Educação Profissional - concepções, experiências, problemas e propostas, ambos realizados em 2003. Os 
suportes normativos expressos nas orientações do Decreto $\mathrm{N}^{\circ}$ 5.154/2004 impulsionaram a oferta do Ensino Médio integrado à Educação Profissional (EMI), que, adotado como política governamental, desenvolve, por meio Departamento de Ensino Médio, da Secretaria de Educação Básica e da Secretaria de Ciência e Tecnologia, ações e estratégias para implementação e para ampliação da oferta de EMI. Tais ações pautavam-se essencialmente na orientação normativa e conceitual de integração curricular, bem como no aparelhamento às secretarias de educação e ciência e tecnologia para o desenvolvimento integrado dos currículos de EMI.

A história que sucedeu o movimento ora contado é objeto de estudo da pesquisa anunciada, pois analisar o desenvolvimento dos currículos de EMI constitui matéria histórica para memória e registro da Educação Profissional.

\section{CONCLUSÃO}

Cumpre-nos, por fim, expressar os achados e os registros fundamentais para as etapas posteriores da pesquisa realizada:

- As análises obtidas nos estudos históricos da Educação Profissional Brasileira revelam sobremaneira que a mudança estrutural e organizacional não acontece só por meio da norma (da lei promulgada), mas também pela política educacional, que consolida as mudanças ou mantém a estrutura segundo seus interesses e suas opções decorrentes. $\mathrm{O}$ que foi normatizado só ganha dimensão histórica quando realizado, pois somente na prática é que a norma se constituirá.

- Historicamente, a disjunção da Educação Profissional em relação ao ensino regular consolidou o status de alienação e de marginalização do trabalho à dimensão formativa dos currículos escolares. Superar essa marca histórica requer, antes de mais nada, clareza dos embates ideológicos que a constituíram.

- Os vestígios de integração curricular que melhor qualificam a unidade conceitual da formação humana foram encontrados nas organizações mais primitivas da sociedade brasileira, pois a formação para o trabalho estava devidamente ligada à cultura e aos conceitos ensinados nas tribos indígenas. 
Os contornos e as nuanças contidos na história da Educação Profissional são suportes arqueológicos significativos para compreensão e análise da identidade conceitual e estrutural observada hoje nas escolas de EMI. Resistências, mudanças e embates são aspectos intrinsecamente relacionados ao passado histórico da Educação Profissional brasileira; não há, portanto, como analisar o presente sem relacioná-lo à sua história. 


\section{REFERÊNCIAS}

ABRAMOVAY, Miriam; CASTRO, Mary Garcia. Ensino Médio: múltiplas vozes. Brasília: Ministério da Educação, 2003.

BOGDAN, Roberto C.; BIKLEN, Sari Knopp. Investigação qualitativa em educação: uma introdução à teoria e aos métodos. Portugal: Porto Editora, 1994.

BRASIL. Conselho Federal de Educação. Parecer No 76, de 21 de janeiro de 1975. Fixa Diretrizes para Educação Básica. Diário Oficial [da] República Federativa do Brasil, Poder Executivo, Brasília, DF, 23 jan. 1975. Seção 1, n. 170, p. 24-50.

BRASIL. Decreto n. 2.208, de 17 de abril de 1997. Diário Oficial [da] República

Federativa do Brasil, Poder Executivo, Brasília, DF, 18 abr. 1997. Seção 1, n. 274, p. 7760 7761.

BRASIL. Decreto No 5.154, de 23 de julho de 2004. Regulamenta o $§ 2^{\circ}-$ do art. 36 e os arts. 39 a 41 da Lei no 9.394, de 20 de dezembro de 1996, que estabelece as diretrizes e bases da educação nacional, e dá outras providências. Diário Oficial [da] República Federativa do Brasil, Poder Executivo, Brasília, DF, 26 jul. 2004. Seção 1, n. 142, p. 18.

BRASIL. Lei No 4.024, de 20 de dezembro de 1961. Fixa as Diretrizes e Bases da Educação Nacional. Diário Oficial [da] República Federativa do Brasil. Poder Legislativo, Brasília, DF, 27 dez. 1961, Seção 1. p. 11.429.

BRASIL. Lei No 5.692, de 11 de agosto de 1971. Fixa as Diretrizes e Bases da Educação Nacional. Diário Oficial [da] República Federativa do Brasil. Poder Legislativo, Brasília, DF, 12 ago. 1971, Seção 1. p. 6377.

BRASIL. Lei $N^{\circ}$ 7.044, de 18 de outubro de 1982. Altera dispositivos da Lei $n^{\circ} 5.692$, de 11 de agosto de 1971, referentes a profissionalização do ensino de $2^{\circ}$ grau. Diário Oficial [da] República Federativa do Brasil, Poder Legislativo, Brasília, DF, 19 out. 1982. p.19539.

BRASIL. Lei No 9.394, de 20 de dezembro de 1996. Estabelece as diretrizes e bases da educação nacional. Diário Oficial [da] República Federativa do Brasil, Poder Legislativo, Brasília, DF, 23 dez. 1996. Seção 1, n. 248, p. 27833-27841.

CIAVATTA, Maria. A formação integrada: a escola e o trabalho como lugares de memória e de identidade. In: FRIGOTTO, Gaudêncio; CIAVATTA, Maria; RAMOS, Marise. (Orgs.). Ensino Médio integrado: concepção e contradições. São Paulo: Cortez, 2005. p. 83-105.

CUNHA, Luiz Antônio. O ensino de ofícios artesanais e manufaturas no Brasil escravocata. São Paulo: UNESP, 2000.

FRIGOTTO, Gaudêncio; CIAVATTA, Maria; RAMOS, Marize. (Orgs.). Ensino Médio integrado: concepção e contradições. São Paulo: Cortez, 2005 
GIL, Antônio Carlos. Como elaborar projetos de pesquisa. 3. ed. São Paulo: Atlas, 1991.

KUENZER, Acacia. Ensino Médio e Profissional: as políticas do estado neoliberal. São Paulo: Cortez, 1997.

KUENZER, Acacia. Ensino Médio: construindo uma proposta para os que vivem do trabalho. São Paulo: Cortez, 2007.

MANFREDI, Silvia Maria. Educação Profissional no Brasil. São Paulo: Cortez, 2002.

\section{NOTAS}

\footnotetext{
${ }^{1}$ Para maior aprofundamento, ver Frigotto, Ciavatta, Ramos (2005) e Abramovay e Castro (2003).

${ }^{2}$ Usado principalmente para o comércio de exportação.

${ }^{3}$ Amplamente desenvolvidos na Europa nesse mesmo período histórico.

${ }^{4}$ A Companhia de Jesus adotava, em suas escolas e seminários, o currículo do Ratio Studiorum.

${ }^{5}$ O Ensino Médio, nesse período, era designado como Ensino Secundário.

${ }^{6} \mathrm{O}$ ciclo de estudos corresponde, hoje, ao Ensino Básico.

${ }^{7}$ Exames aplicados no final de um período escolar, cujo caráter era o de promover ou não o aluno para a etapa seguinte.

${ }^{8}$ Os egressos dos cursos profissionais tinham de fazer um curso de adaptação e, por meio desse curso, eram verificadas as condições para a formação pretendida.

${ }^{9}$ No texto A gênese do Decreto $N^{o}$ 5.154/2004: um debate no contexto controverso da democracia restrita, os autores citados fazem uma memória como partícipes históricos das discussões e das proposições vividas antes, durante e depois da promulgação.

${ }^{10}$ Uma das causas que gerou o movimento de revogação do Decreto.
} 